JERZY RAJMAN

\title{
IMIĘ STANISŁAW WŚRÓD MIESZCZAN KRAKOWSKICH DO 1333 ROKU
}

„Katalog imion chrzestnych w Polsce średniowiecznej pokrywa się w zasadzie $\mathrm{z}$ istniejącymi u nas kultami boskich wspomożycieli, ich wezwaniami i relikwiami". Zdanie to, napisane przed laty przez Kazimierza Dobrowolskiego, autora monograficznego ujęcia kultu św. Floriana, stanowi aktualny do dziś postulat badawczy. Gdyby jednak żądać od badaczy jasnej i konkretnej odpowiedzi na pytanie, czy imię Stanisław było popularne w społeczeństwie Polski średniowiecznej, to uczciwie należałoby odpowiedzieć: nie wiemy ${ }^{1}$. Niniejszy komunikat nie wypełni, rzecz oczywista, luki, jaką jest brak pełnego rozeznania dróg szerzenia się imienia Stanisław i skali jego popularności. Nie doczekaliśmy się, w odniesieniu do średniowiecznego Krakowa, takiego choćby opracowania wpływu kultu świętych na imiennictwo, jakie $\mathrm{H}$. Bruningk przedstawił na przykładzie średniowiecznej Rygi ${ }^{2}$. Moim zadaniem jest ukazanie, w jakim zakresie imię Świętego Biskupa znalazło oddźwięk wśród tych, którzy mogli co dzień obcować $\mathrm{z}$ jego grobem, głównym ośrodkiem kultu, a zatem wśród mieszczan krakowskich. Przyjęta cezura roku 1333 podyktowana została świeżo ukończoną przeze mnie monografią wczesnych dziejów Krakowa, zawierającą

${ }^{1}$ K. D o b row o $1 \mathrm{sk}$ i, Dzieje kultu św. Floriana w Polsce do połowy XVI wieku, Warszawa 1923, s. 51. Istnieje zestawienie J. B y s t r o n i a, Księga imion w Polsce używanych, Warszawa 1938, który na s. 319 wykorzystuje dla ukazania zjawiska populamości imienia Stanisław „akta krakowskie” z lat 1390-1416. Na tym, bardzo niepelnym, opracowaniu oparł swe wywody T. U l e w i c z, Święty Stanisław ze Szczepanowa w kulturze umystowo-literackiej dawnej Polski, „Analecta Cracoviensia" t. 11 (1979), s. 463 i nast.; zob. także W. T a s z y c k i, Najdawniejsze polskie imiona osobowe, Rozprawy Akademii Umiejętności, Wydział Filologiczny, t. 62, 1925, nr 3, s. 97.

${ }^{2} \mathrm{H}$. B r u n in g k, Der Einfluss der Heiligenverehrung auf die Wahl der Taufnamen in Riga im Mittelalter, „Sitzungsberichte der Gesell. für Geschichteund Altertumskunde der Ostseeprovinzen Russlands", Riga 1903. 
studium prosopograficzne nad mieszczaństwem, które zostało doprowadzone do roku śmierci Władysława Łokietka ${ }^{3}$.

Najwcześniejszym przykładem występowania pełnej formy imienia Stanisław wśród mieszczan krakowskich jest Stanisław, wzmiankowany w $1311 \mathrm{r}$. jako szwagier wójta. Wiadomo o nim niestety tylko tyle, że ustapił z ćwierci swego dziedzictwa przy ul. św. Jana kramarzowi Mikołajowi ${ }^{4}$. Ów Stanisław był zapewne bratem nieznanej z imienia żony wójta Alberta.

Wielokrotnie w źródłach miejskich występował (ok. 1322 - ok. 1332) ławnik Mikołaj, syn wójta Jaszka. Z zapiski sporządzonej po jego śmierci w 1332 r. wiadomo, że wdowa po nim miała na imię Katarzyna, zaś synowie Mikołaj i Stanisław ${ }^{5}$. Kupiec Mikołaj Scrammon miał synów Peszka, Stanisława i Hencila, którzy w 1323 r. ustapili z trzech ćwierci gruntu przy ul. św. Jana Hejnuszowi Kutilerowi ${ }^{6}$.

W 1328 r. wzmiankowany jest Stanisław Polak piszacy się ze Skalbmierza. Kupił wówczas półtorej ćwierci przy ulicy Krzyża Świętego od Hermana, krewnego Fryczka z Grimme?

$\mathrm{Z}$ tego samego roku znany jest Stanisław, syn Alberta kowala. Ustapił on ogród koło kościoła św. Jakuba Staszkowi pisarzowi. Następnie sprzedał za 5 grzywien ogród koło tego kościoła Staszkowi słodownikowi ze słodowni koło kościoła Św. Krzyża ${ }^{8}$.

Stanisław, syn mieszczanina zapisanego jako Vllebuch, pojawił się w 1317 roku przy okazji transakcji, którą zawarł z Zofią żoną Czasława. Uzyskał wówczas dom przy ulicy św. Jana. W 1318 r. wzmiankowany jest jako Stanus Vulbuch. Ustapił wówczas z połowy kramu Gerhardowi kupcowi, zaś w 1325 r. uzyskał jatkę rzeźniczą od Piotra Czecha. W księdze miejskiej zapisano go wówczas jako Stanusza Vllebucha ${ }^{9}$. Ojcem wzmiankowanego tu Stanisława był niewątpliwie ławnik zapisany w 1306 r. jako Hencze Vllebuch, jego zaś z kolei możemy identyfikować z mieszczaninem zapisanym jako Hencze Buchil, bądź po prostu Buchel, o którym wiadomo, że był rzeźnikiem i w latach $1289 / 90$ oraz 1300 zasiadał wśród ławników ${ }^{10}$.

${ }^{3}$ J. R a j m a n, Kraków. Zespòt osadniczy, lokacja i mieszczanie do 1333 r., Wydawnictwo Naukowe Akademii Pedagogicznej w Krakowie, w druku. Dla późniejszego okresu brak pełnych zestawień mieszczan krakowskich.

${ }^{4}$ Podstawę źródłową stanowią Najstarsze ksieggi i rachunki miasta Krakowa, wyd. F. Piekosiński i J. Szujski, Kraków 1878 (dalej KRK), nr 198

${ }^{5}$ KRK 1081 .

${ }^{6}$ KRK 685.

${ }^{7}$ KRK 977.

${ }^{8}$ KRK 951, 961.

${ }^{9}$ KRK 441, 442, 526, 776.

${ }^{10}$ KRK s. 9 (Hencze Vllebuch) oraz inne KRK nr 1 (1300) i KRK nr 25. 
Zapiski o synu Vullebucha wskazują że interesujące nas imię nawet w przypadku jednej i tej samej osoby zapisywano jako Stanisław, a zatem w pełnej formie, oraz w formie zdrobniałej Stanusz. W księdze miejskiej zachowało się kilka wzmianek o mieszczanach używających zdrobniałych form imienia. Najwcześniej jest poświadczony Staszko krawiec, który w 1310 r. zastawił część dworu Gotfrydowi z Nysy, potem zastawił mu jeszcze ćwierć za 6 grzywien i 8 skojcy, zaś w 1313 r. ustapił z ćwierci posesji przy ulicy św. Floriana Bratkowi Polakowi ${ }^{11}$. Wiadomo także, że ustapił z półtorej posesji kupcowi Piotrowi Czarnemu'2.

W 1318 r. występuje słodownik Stanko, który wszedł w posiadanie części parceli przy ulicy Krzyża Świętego przejmując ją z rąk Hejnka Jewita ${ }^{13}$. Zapewne tegoż Stanka słodownika dotyczy zapiska z 1325 r., iż ustapił Hermanowi połowę dworu przy ulicy Krzyża Świętego, zaś swej matce Jadwidze ustąpił 2 kramy koło klasztoru dominikanów ${ }^{14}$.

W 1328 r. pojawił się Staszko słodownik, zapewne inny niż wspomniany wyżej Stanko. Ustapił ćwierć usytuowaną za swoim dworem Jakelowi, słudze Jana archidiakona sandomierskiego. Zrzekł się, w imieniu rycerza Dzierżka, praw do półtorej ćwierci koło szpitala kramarzowi Piotrowi Czarnemu ${ }^{15}$.

Stanko Polak sprzedał w 1315 r. połowę dworu przy ulicy św. Floriana Michałowi Polakowi ${ }^{16}$. W 1317 r. pojawił się Staszko szewc, o którym wiadomo tylko, że w 1317 r. ustapił z ćwierci przy ulicy św. Szczepana na rzecz Jana Polaka ${ }^{17}$.

Zdrobniałej formy, Staszko, używał pisarz miejski, wzmiankowany po raz pierwszy w 1312 r., kiedy wszedł w posiadanie części posesji przy szpitalu od Henryka $\mathrm{z}$ Dornburga ${ }^{18}$. Z końca badanego okresu znany jest wójt Staszko, wzmiankowany w 1329 i 1331 roku $^{19}$.

Nieznany bliżej Stanko miał syna Peszka, który w 1326 r., występując jako opiekun swej matki, ustapił wraz z nią z ćwierci gruntu przy ul. Szewskiej Marcinowi Polakowi i Mikołajowi Wierzynkowi, tak jednak, aby matka mogła tam posiadać izbę oraz miejsce do trzymania 2 świń. Matka wzmiankowana jest w tej zapisce bezimiennie, jako „Stankonissa”20.

\footnotetext{
${ }^{11}$ KRK 128, 137, 279.

${ }^{12}$ KRK 788.

${ }^{13}$ KRK 520.

${ }^{14}$ KRK 769770.

${ }^{15}$ KRK 914, 958.

${ }^{16}$ KRK 330.

${ }^{17}$ KRK 395.

${ }^{18}$ KRK 248.

${ }^{19}$ KRK s. 98; KRK 1045.

${ }^{20}$ KRK 862.
} 
Na uwage zasługuje postać Staszka Wasiłowicza. Zapis jego nazwiska Wassilovicz - wskazuje, że jego ojcem był nieznany bliżej Wasyl. Staszek miał siostrę Małgorzatę, która w $1318 \mathrm{r}$. ustapiła mu z wszelkich praw do dworu. W tym samym roku Staszek zrzekł się praw do ćwierci dworu na rzecz swojej siostry Katarzyny, zaś Wacław, jej mąż, ustapił jej z połowy dworu przy ul. św. Floriana. W 1328 r. ustapił Mikołajowi kramarzowi, krewnemu Henryka z Egeru, słodownię glinianą. W 1332 r. Staszek Wasiłowicz ustapił z wszystkich swoich dóbr swojemu synowi Piotrowi ${ }^{21}$.

Interesujące nas imię występuje również w formie żeńskiej. W $1318 \mathrm{r}$. Stanisława wdowa po Bartłomieju Sanxis, występowała przed sądem ławniczym w sprawie o $1 / 2$ dworu, która jej zmarły mąż ustapił z tytułu swego długu Henrykowi Vinrichowi, ojcu Hanka, co potwierdził Hejnman z Muchowa. Wzmiankowana jest jeszcze w 1332 r., jako wdowa Stanisława wraz z córką Zalką i wnuczką Alka, kiedy ustapiła swojemu synowi Leksikowi dom przy ulicy Garncarzy na rogu, naprzeciw magistra jurysty Bertolda ${ }^{22}$. Imię to nosiła także wdowa po Winrichu, która w 1323 r. daje zięciowi Hilbrandowi z Dębna młyn w Tarczku, rybnik i wójtostwo w Leśrej. Występuje także drugi zięć, Bertold, soltys Dąbrowy ${ }^{23}$.

Powyższe zapiski, cytowane możliwie jak najwierniej z najstarszej księgi miejskiej, mogą służyć nie tylko prostemu wyliczeniu, ilu Stanisławów żyło w Krakowie przed 1333 rokiem. Przytoczone fakty z życiorysów interesujących nas mieszczan umożliwiają szkicowe nakreślenie środowisk, $\mathrm{z}$ których pochodzili ludzie noszący imię Stanisław. Zestawienie to wskazuje, że imię Stanisław (lub w formie zdrobniałej) występuje w rodzinach, w których poświadczone są imiona niemiecko brzmiące Albert i Hencze, polsko brzmiące Jaszko, czy rusko brzmiące Wasyl. Imię Stanisław napotykamy w rodzinach wójtów, ławników, pisarzy miejskich, kupców, rzeźników, kowali, słodowników i szewców. Jest to wniosek ważny, gdyż zestawienie to wskazuje niezbicie, że imię to miało wówczas zasięg szeroki, nie ograniczający się do jednej grupy mieszczan.

${ }^{21}$ KRK 490, 510, 981, 1128.

${ }^{22}$ KRK 475; K 1096.

${ }^{23} \mathrm{KK}$ 1, s. 160; J. P t a śn i k, Studya nad patrycjatem krakowskim wieków średnich, cz. 1, „Rocznik Krakowski” t. 15 (1913), s. 53. 


\section{The Name Stanislaus among Cracow Burghers until 1333} Summary

The name Stanislaus (or its diminutive form) appears in Cracow burghers' families in which names that sounded German, Polish or Ruthenian were recorded. We come across the name Stanislaus in the families of mayors of villages, aldermen, scribes, merchants, butchers, blacksmiths, maltsters and shoemakers. It can be inferred that the appearance of this name was widespread and encompassed all groups of burghers, which may be regarded as indirect proof of the popularity of the worship of St. Stanislaus. 